\title{
DUKUNGAN SUAMI TERHADAP PEMBERIAN ASI EKSKLUSIF DI WILAYAH KERJA PUSKESMAS LUBUK KILANGAN KOTA PADANG TAHUN 2011
}

\author{
Vetty Priscilla ${ }^{1}$, Dwi Novrianda ${ }^{1}$, Suratno $^{2}$ \\ ${ }^{1}$ Staf Dosen Fakultas Keperawatan Universitas Andalas \\ ${ }^{2}$ Mahasiswa Fakultas Keperawatan Universitas Andalas \\ e-mail: vettypriscilla@gmail.com
}

\begin{abstract}
Dukungan suami merupakan indikator pendukung keberhasilan program pemberian ASI eksklusif. Untuk itu kesadaran suami agar mau melibatkan diri dalam hal pemberian dukungan kepada ibu selama proses pemberian ASI sejak awal kelahiran perlu ditingkatkan. Penelitian bertujuan untuk mengetahui hubungan antara dukungan suami dengan pemberian ASI eksklusif di Wilayah Kerja Puskesmas Lubuk Kilangan Kota Padang. Jenis penelitian adalah deskriptif korelasi dengan rancangan cross sectional study. Penelitian dari bulan Agustus 2010 sampai Juni 2011. Sampel diambil secara acak menggunakan teknik cluster sampling dengan jumlah sampel 82 orang ibu. Instrumen pengumpulan data menggunakan kuesioner. Data dianalisis menggunakan uji chi square dan logistic regression. Hasil penelitian diperoleh bahwa dukungan instrumental dan penilaian bernilai positif sedangkan dukungan emosional dan informasional bernilai negatif. Selanjutnya terdapat hubungan yang bermakna antara dukungan emosional, instrumental, informasional, dan penilaian suami terhadap pemberian ASI eksklusif. Dukungan penilaian merupakan variabel yang paling tinggi kekuatan hubungannya terhadap pemberian ASI eksklusif $(b=0.119)$. Peneliti menyarankan agar tenaga kesehatan memperluas sasaran promosi kesehatan yang berhubungan dengan pemberian ASI eksklusif yang melibatkan suami sebagai sasaran.
\end{abstract}

Kata kunci : ASI eksklusif, dukungan suami, dukungan penilaian.

Abstrak: Husband's support is an indicator of the success of programs supporting exclusive breastfeeding. So the consciousness of the husband involving themselves in providing support to the mother's during the process of breastfeeding since the beginning of birth needs to be improved. The study aimed to determine the relationship between husbands support and exclusive breastfeeding in the Lubuk Kilangan Public Health Center, Padang. It is a descriptive correlation design using cross-sectional study. Research held from August 2010 until June 2011. Sampling technique was cluster sampling with 82 mothers. Data was obtained using questionnaire. Analysis data used chi square tests and logistic regression test. The results showed that instrumental and appraisal support was positive whereas emotional and informational support was negative. Then, there is a significant association between emotional, instrumental, informational, and appraisal support and exclusive breastfeeding. Appraisal support was the highest variable related to exclusive breastfeeding $(b=0119)$. Researchers suggest that expanding health goals related to health promotion of exclusive breastfeeding involving the husband as the target.

Key words: exclusive breastfeeding, husband's support, appraisal support.

Berdasarkan SDKI tahun 2006-2007, sama dilakukan pada tahun 2002. Data pemberian ASI Eksklusif di bawah 6 bulan Susenas (2007-2008) cakupan pemberian ASI menurun, dibandingkan dengan survei yang eksklusif pada bayi 0-6 bulan menurun dari 
62,2\% di tahun 2007 menjadi 56,2\% pada tahun 2008. Sedangkan cakupan pemberian ASI eksklusif pada bayi sampai 6 bulan turun dari $28,6 \%$ tahun 2007 menjadi $24,3 \%$ di tahun 2008 dan jumlah bayi di bawah 6 bulan yang diberi susu formula meningkat dari 16,7\% pada tahun 2002 menjadi $27,9 \%$ pada tahun 2007 (Depkes RI, 2010).

Pedoman internasional yang menganjurkan pemberian ASI eksklusif selama 6 bulan pertama didasarkan pada bukti ilmiah tentang manfaat ASI bagi daya tahan hidup bayi, pertumbuhan, dan perkembangannya. ASI memberi semua energi dan gizi (nutrisi) yang dibutuhkan bayi selama 6 bulan pertama hidupnya. Pemberian ASI eksklusif mengurangi tingkat kematian bayi yang disebabkan berbagai penyakit yang umum menimpa anak-anak seperti diare dan radang paru, serta mempercepat pemulihan bila sakit dan membantu menjarangkan kelahiran (Linkages, 2002).

Suatu penelitian yang dilakukan oleh Edmond di Ghana pada tahun 2006 yang diterbitkan dalam jurnal Pediatrics menunjukkan 16\% kematian bayi dapat dicegah melalui pemberian ASI pada bayi sejak hari pertama kelahirannya. Angka ini naik menjadi 22\% jika pemberian ASI dimulai dalam satu jam pertama setelah kelahiran bayi (Baskoro, 2008). Sudah menjadi kenyataan bahwa angka kesakitan (morbiditas) dan kematian (mortalitas) bayi yang diberi ASI eksklusif jauh lebih kecil dibandingkan dengan bayi yang tidak mendapatkan ASI eksklusif (Roesli, 2001).

Banyaknya bayi yang tidak mendapatkan ASI eksklusif di Indonesia disebabkan oleh berbagai faktor, diantaranya dukungan dari berbagai pihak yang masih kurang, salah satunya dukungan suami. Keberhasilan ASI eksklusif dapat dicapai bila dukungan dari suami turut berperan. Menyusui memerlukan kondisi emosional yang stabil, mengingat faktor psikologis ibu sangat mempengaruhi produksi ASI, suami dan istri harus saling memahami betapa pentingnya dukungan terhadap ibu yang sedang menyusui (Tasya, 2008).

Dari hasil penelitian Owens (dikutip dalam Kemalasari, 2009) mengatakan kurangnya dukungan suami dalam pemberian ASI eksklusif karena anggapan bahwa menyusui menyebabkan ibu menjadi jelek, tidak menarik dan dapat menghambat atau meninggalkan hubungan seks antara suami dan istri. Widjaja (2007) mengatakan ada juga sebagian ibu yang merasa enggan menyusui karena dianggap menghalangi keleluasaan geraknya, dan memiliki perasaan takut merusak bentuk payudara sehingga bayinya cukup diberikan susu formula.

Roesli (2007) juga mengatakan bahwa masih populer pendapat yang mengatakan bahwa menyusui hanya urusan ibu saja, tidak ada kaitannya dengan ayah. Pendapat lain juga dikatakan oleh Paramita (2007), minimnya dukungan ayah dalam praktek pemberian ASI akibat faktor kebiasaan budaya dimana dimana ayah hanya berperan dan berkewajiban sebagai pencari nafkah dan urusan rumah tangga semuanya diurus oleh istri termasuk urusan menyusui.

Rendahnya cakupan ASI eksklusif secara Nasional tentunya perlu mendapat perhatian lebih. Penggalakan ASI memang bukan hal yang baru namun berbagai upaya untuk meningkatkannya terus dilakukan baik oleh pemerintah maupun swasta dan juga masyarakat peduli ASI. Meskipun hasil yang diharapkan belum mencapai target nasional yaitu $80 \%$ dan rendahnya cakupan ASI eksklusif tersebut tentunya dimulai dari rendahnya pencapaian program ASI eksklusif 
pada setiap Propinsi dan wilayah Kabupaten/Kota di Indonesia. Di antaranya di Propinsi Sumatera Barat (Sumbar) pada tahun 2008 lalu cakupan ASI eksklusifnya hanya sebesar 56,61\%, dan sangat disayangkan untuk data ASI ekslusif di Kota Padang sendiri sebagai Ibukota Propinsi Sumbar cakupan ASI eksklusifnya berada pada urutan ke-14 terendah yaitu sebesar 40,5\% dari 19 Kota/Kabupaten yang ada dan $69,2 \%$ pada tahun 2009 (Dinkes Provinsi Sumbar, 2008 dan Dinkes Kota Padang, 2009).

Cakupan ASI eksklusif dari 11 Kecamatan di Kota Padang ternyata pencapaian di Kecamatan Lubuk Kilangan menduduki peringkat terendah dibandingkan dengan Kecamatan lain, dimana tingkat pencapaian ASI eksklusifnya sebesar 36.5\% (DKK Padang, 2010). Fenomena tersebut diperkuat dengan hasil survei awal yang telah dilakukan diketahui bahwa jumlah ibu yang menyusui secara eksklusif penuh selama 6 bulan relatif sedikit di tahun 2010. Berdasarkan data KIA hanya $302 \mathrm{ibu}$ yang memberikan ASI esklusif dari 787 jumlah kelahiran bayi di 7 Kelurahan yang ada di Kecamatan Lubuk Kilangan pada periode tahun 2010. Bahkan dari 10 sampel pada survei awal pemberian ASI esklusif masing-masing ibu hanya berkisar pada usia bayi antara 2-3 bulan saja dan ada bayi yang tidak mendapat ASI eksklusif sejak lahir dengan alasan ibu ASI belum keluar di hari pertama setelah melahirkan sehingga bayi diberi susu formula. Sementara itu keikutsertaan para suami dalam masalah pemberian ASI juga belum mengarah pada kegiatan yang mendukung ibu untuk bisa memberikan ASI secara eksklusif dengan sempurna. Hal inilah yang mendorong peneliti untuk melakukan penelitian tentang hubungan antara dukungan suami dan pemberian ASI eksklusif.

\section{Metode}

Jenis penelitian yang digunakan dalam penelitian ini adalah deskriptif corelasional dengan rancangan cross sectional study. Populasi penelitian ini adalah semua ibu yang mempunyai bayi usia 7-12 bulan yang berada di Wilayah Kerja Puskesmas Lubuk Kilangan Kota Padang. Pada survei awal diperoleh data kelahiran neonatus dari bulan April sampai Oktober 2010 dalam laporan bulanan PWS Puskesmas Lubuk Kilangan diperoleh data jumlah bayi lahir yang diperkirakan telah berusia 7-12 bulan pada saat dilakukan penelitian pada bulan Mei 2011 sebayak 451 bayi dari 7 kelurahan di Wilayah Kerja Puskesmas Lubuk Kilangan. Pengambilan sampel dalam penelitian ini dilakukan secara cluster sampling (secara kelompok atau gugus). Kriteria sampel yang diikutkan pada penelitian ini adalah ibu yang bersedia menjadi responden, mempunyai bayi berusia antara 7-12 bulan, dengan harapan responden masih mampu mengingat kejadian dan kebiasaan bersama suami selama ibu memberikan ASI kepada bayi saat usia bayi antara 0 bulan sampai 6 bulan. Ibu yang memiliki bayi yang pernah dirawat di rumah sakit selama usia 0-6 bulan akan dikeluarkan menjadi sampel. Berdasarkan rumus pengambilan sampel, diperoleh sebanyak 82 orang. Selanjutnya untuk mencari gugus atau kelompok sampel dari setiap kelurahan maka digunakan rumus oleh Narbuko \& Achmadi (2007) berikut:

jumlah sampel $=\frac{\text { jumlah populasi di kelurahan }}{\text { jumlah keseluruhan populasi }} x$ jumlah sampel 
Tabel 1. Jumlah sampel pada tiap Kelurahan yang akan dijadikan sampel

\begin{tabular}{clcc}
\hline No. & Desa/Kelurahan & Perhitungan & Jumlah sampel \\
\hline 1. & Bandar buat & $141 / 451 \times 82$ & 25 \\
2. & Padang besi & $67 / 451 \times 82$ & 12 \\
3. & Indarung & $118 / 451 \times 82$ & 21 \\
4. & Koto lalang & $57 / 451 \times 82$ & 10 \\
5. & Batu gadang & $47 / 451 \times 82$ & 9 \\
6. & Baringin & $14 / 451 \times 82$ & 3 \\
7. & Tarantang & $7 / 451 \times 82$ & 2 \\
\hline \multicolumn{5}{c}{} \\
\hline
\end{tabular}

Penelitian telah dilaksanakan dari bulan Agustus 2010 sampai bulan Juli 2011. Instrumen penelitian berupa kuesioner yang terdiri atas 3 bagian. Bagian pertama digunakan untuk mengkaji karakteristik atau data demografi responden. Bagian kedua untuk menggali dukungan suami terhadap pemberian ASI eksklusif yang meliputi dukungan emosional, instrumental, informasional, penilaian/apprasial. Bagian ketiga untuk mengkaji apakah pemberian ASI eksklusif diberikan atau tidak sewaktu usia bayi 0-6 bulan sebelumnya. Kuesioner dukungan suami berkaitan dengan perilaku maka pengukuran nilai skor digunakan skala likert yaitu: "tidak pernah", "jarang", "sering", "selalu", "sangat selalu". Jumlah pernyataan pada masing-masing bentuk dukungan suami terdiri dari 6 pernyataan.

Data diolah dengan menggunakan statistik Chi-Square untuk melihat hubungan variabel independen dengan variabel dependen dengan tingkat kemaknaan $\mathrm{p}<0,05$. Lebih lanjut untuk mengetahui variabel independen yang paling dominan berhubungan dengan variabel dependen digunakan logistic regression dengan nilai $\mathrm{p}<0,25$.

\section{Hasil Penelitian}

Pengumpulan data pada tanggal 3-26 Mei 2011 di Wilayah Kerja Puskesmas Lubuk Kilangan Kota Padang diperoleh karakteristik responden berdasarkan umur, pendidikan dan pekerjaan ibu (Tabel 2).

Pada tabel 2 dapat dilihat bahwa usia ibu terbanyak adalah usia antara 31-35 tahun sebanyak $30 \mathrm{ibu}(36,6 \%)$, pendidikan ibu terbanyak adalah tamat SMA/Sederajat sebanyak 32 orang ibu $(39,1 \%)$ dan beberapa orang ibu tidak sekolah yaitu 7 orang $(8,5 \%)$. Lebih lanjut dapat dilihat bahwa kebanyakan ibu adalah sebagai ibu rumah tangga yaitu 78 ibu $(95,2 \%)$.

\section{Tabel 2. Karakteristik responden}

\begin{tabular}{clcc}
\hline No. & Karakteristik & F & \% \\
\hline 1. & Umur & & \\
& $21-25$ & 12 & 14,6 \\
& $26-30$ & 29 & 35,4 \\
& $31-35$ & 30 & 36,6 \\
& $36-43$ & 11 & 13,4 \\
\hline 2. & Pendidikan ibu & & \\
\hline
\end{tabular}




\begin{tabular}{llcc}
\hline & Tidak sekolah & 7 & 8,5 \\
& SD & 16 & 19,5 \\
SMP & 25 & 30,5 \\
& SMA/sederajat & 32 & 39,1 \\
& Perguruan tinggi & 2 & 2,4 \\
\hline 3. & Pekerjaan ibu & & \\
& Ibu rumah tanga & 78 & 95,2 \\
& Wiraswasta & 2 & 2,4 \\
& Pegawai swasta & 1 & 1,2 \\
Pegawai negeri & 1 & 1,2 \\
\hline
\end{tabular}

Dukungan suami berupa dukungan emosional (52,7\%), dan dukungan penilaian positif diperoleh sebagian besar menyatakan negatif (54,9\%). Kemudian lebih dari sebagian (52,5\%), dukungan instrumental positif responden tidak memberikan ASI eksklusif $(56,1 \%)$, dukungan informasional negatif $(82,03)$ (Tabel 3).

Tabel 3. Distribusi frekuensi dukungan suami dan pemberian ASI eksklusif

\begin{tabular}{clcc}
\hline No. & Variabel & F & \% \\
\hline 1. & Dukungan emosional & 39 & 47,5 \\
& Positif & 43 & 52,5 \\
Negatif & & \\
2. & Dukungan instrumental & 46 & 56,1 \\
& Positif & 36 & 43,9 \\
Negatif & 38 & 46,3 \\
3. Dukungan informasional & 44 & 52,7 \\
& Positif & & \\
4egatif & 45 & 54,9 \\
& Positif & 37 & 45,1 \\
Negatif & & 17,07 \\
& Pemberian ASI eksklusif & 14 & 82,03 \\
\hline
\end{tabular}

Tabel 4. Uji Chi Square dukungan emosional dan pemberian ASI eksklusif

\begin{tabular}{lccc}
\hline Dukungan suami & \multicolumn{2}{c}{ ASI eksklusif } & p Value \\
& Ya & Tidak & \\
\hline Emosional & $27(69,2 \%)$ & $12(30,8 \%)$ & 0,002 \\
Positif & $41(95,3 \%)$ & $2(4,7 \%)$ & \\
Negatif & & & 0,014 \\
Instrumental & $34(73,9 \%)$ & $12(26,1 \%)$ & \\
Positif & $34(94,4 \%)$ & $2(5,6 \%)$ & 0,008 \\
Negatif & & &
\end{tabular}




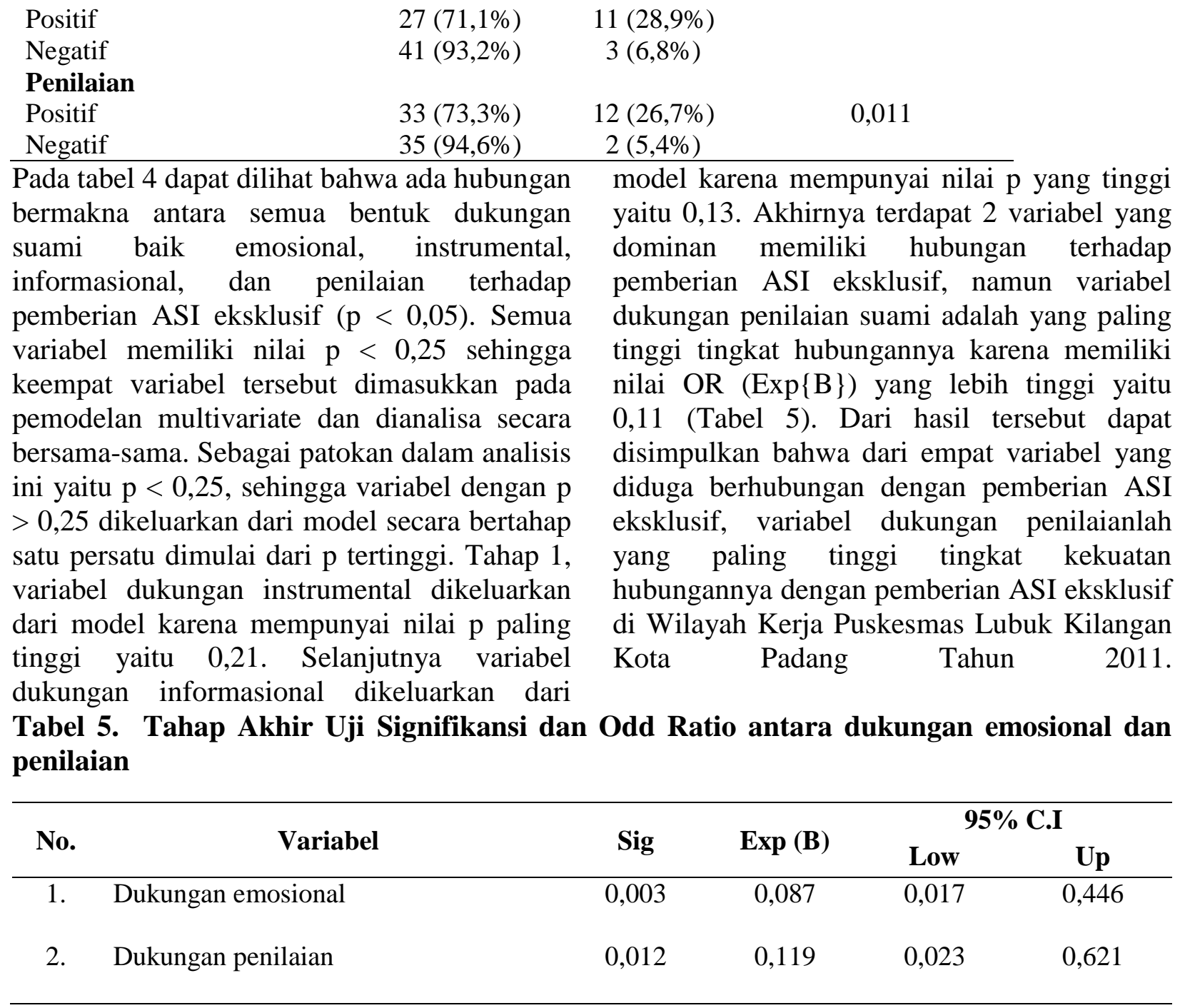

\section{Hasil Dan Pembahasan}

Berdasarkan hasil penelitian terlihat bahwa nilai $\mathrm{p}=0,002$. Hal ini menyatakan bahwa ada hubungan yang bermakna antara dukungan suami terhadap pemberian ASI eksklusif di Wilayah Kerja Puskesmas Lubuk Kilangan Kota Padang Tahun 2011.

Dari analisis univariat terlihat bahwa hasil persentase dukungan emosional suami negatif adalah lebih tinggi yaitu $43 \mathrm{ibu}$ $(52,5 \%)$ sedangkan dukungan emosional positif lebih rendah yaitu 39 ibu (47,5\%). Tetapi pada uji Chi-Square memperlihatkan bahwa antara dukungan emosional suami terhadap pemberian ASI eksklusif terdapat hubungan yang bermakna antara kedua variabel. Hal ini terjadi karena dari $43 \mathrm{ibu}$ $(52,5 \%)$ yang memiliki dukungan emosional suami negatif masih terdapat 2 ibu $(4,7 \%)$ yang memberikan ASI eksklusifnya dan dari 39 ibu (47,5\%) yang mendapat dukungan emosional positif ada 12 ibu (30,8\%) yang memberikan ASI eksklusif.

Setelah dilakukan analisa pada hasil dukungan suami secara umum dari $27 \mathrm{ibu}$ $(69,2 \%)$ yang memiliki dukungan emosional 
positif namun tidak memberikan ASI eksklusif disebabkan oleh berbagai hal seperti dukungan instumental, informasional, dan penilaian suami yang masih negatif. Selain itu usia ibu dan jumlah anak pada hasil analisa diketahui bahwa rata-rata ibu yang memperoleh dukungan secara umum positif adalah ibu dengan usia antara 21-30 tahun dengan jumlah anak antara satu dan dua anak, ini menandakan bahwa kecenderungan ibu dengan jumlah anak sedikit cenderung mau dan berhasil melaksanakan program ASI eksklusif. Hal ini juga mendukung pendapat Soetjiningsih (1997) bahwa ibu usia muda atau usia produktif cenderung memiliki jumlah volume ASI lebih banyak dibandingkan dengan ibu usia tua atau di atas usia produktif dan perubahan volume ASI pada anak pertama dengan anak berikutnya juga mengalami peningkatan volume ASI.

Berdasarkan hasil penelitian terlihat bahwa nilai $p=0,014$. Hal ini menyatakan bahwa ada hubungan yang bermakna antara dukungan suami terhadap pemberian ASI eksklusif di Wilayah Kerja Puskesmas Lubuk Kilangan Kota Padang Tahun 2011.

Dari 36 ibu $(43,9 \%)$ yang memiliki dukungan instrumental negatif ada 2 ibu $(5,6 \%)$ yang tetap memberikan ASI eksklusifnya. Hal ini terjadi karena dari keempat bentuk dukungan suami yang diperoleh oleh 2 orang ibu, masing-masing ibu masih memiliki dukungan emosional, informasional, dan penilaian suami yang positif. Hal ini membuktikan bahwa keempat dukungan suami merupakan suatu kesatuan yang tidak dapat terpisahkan karena masing-masing dukungan saling memberi pengaruh. Hal ini sesuai dengan pendapat Caplan (1976) (dikutip dalam Friedman, 1998) menjelaskan bahwa keluarga memiliki fungsi dukungan yaitu dukungan informasional, dukungan penilaian, dukungan isntrumental dan dukungan emosional yang saling berkaitan.

Responden yang memiliki dukungan instrumental positif sebanyak 46 ibu $(56,1 \%)$ namun terdapat 34 ibu $(73,9 \%)$ yang tidak memberikan ASI eksklusif, sementara yang memberikan ada 12 ibu (26,1\%). Hal ini terjadi karena meskipun dukungan instrumental suami positif ternyata alasan repot karena pekerjaan rumah, mengurus anak lain, sambil bekerja, dan lainnya masih menjadi alasan ibu tidak bisa memberikan ASI eksklusif. Setelah dilakukan analisa masalah ternyata dari 34 responden $(77,3 \%)$ yang memiliki dukungan instrumental positif namun tidak memberikan ASI eksklusif diperoleh 15 ibu $(34,1 \%)$ diantaranya memiliki dukungan emosional yang negatif dan menurut Baskoro (2008) bahwa selama proses menyusui keadaan emosional ibu sangat mempengaruhi kelancaran pengeluaran ASI karena emosional ibu mempengaruhi kelancaran produksi hormon prolaktin dan oxitocyn yang berperan memproduksi dan mengeluarkan ASI selama proses menyusui.

Jika suami saat berada dirumah mau melibatkan diri dalam hal memberikan bantuan langsung kepada ibu seperti membantu merawat bayi, menggendong, menidurkan, mengerjakan pekerjaan rumah tentunya ibu akan merasa lebih terjaga kondisi emosionalnya dan ibupun dapat menggunakan waktu yang cukup untuk merawat dan memberikan ASI-nya karena tidak adanya kekuatiran bahwa pekerjaannya belum selesai dan takut bayi akan terbangun saat ibu sedang bekerja yang akan menjadikan ibu merasa kerepotan karena harus bekerja sendiri untuk mengurus keperluan rumah, anak-anak, dan juga si bayi tentunya..

Berdasarkan hasil penelitian terlihat bahwa nilai $p=0,008$. Hal ini menyatakan bahwa ada hubungan yang bermakna antara dukungan 
suami terhadap pemberian ASI eksklusif di wilayah kerja Puskesmas Lubuk Kilangan Kota Padang Tahun 2011.

Dari 44 ibu $(53,4 \%)$ yang memiliki dukungan informasional negatif terdapat 3 ibu $(6,8 \% \%)$ yang tetap memberikan ASI eksklusif dan 41 ibu $(93,2 \%)$ tidak memberikan. Hal ini terjadi karena dari 3 orang ibu $(6,8)$ yang memiliki dukungan negatif tersebut 2 responden ibu $(4,5 \%)$ diantaranya masih memiliki dukungan emosional, instrumental, dan penilaian yang positif dari suami dan $1 \mathrm{ibu}(2,3 \%)$ masih memiliki dukungan emosional dan instrumental positif. Keberhasilan ASI eksklusif tersebut juga disebabkan oleh faktor usia ibu yang masih muda dengan anak pertama, dan karena dukungan emosional dan instrumental suami yang positif maka produksi ASI ibu lancar dan mencukupi.

Selain itu dari analisa pada hasil kuesioner diperoleh data bahwa selain dukungan suami ternyata ibu juga memperoleh dukungan dari pihak lain selain suami, dimana alasan para ibu yang memberikan ASI eksklusif diantaranya karena mendapat dukungan informasional dan emosional dari bidan/ penolong persalinan sebanyak $11 \mathrm{ibu}(14,4 \%)$, dan mendapat saran dari keluarga (orang tua, saudara, suami, dan lainnya) sebanyak 6 orang ibu $(7,3 \%)$. Sesuai dengan pendapat Tasya (2008) bahwa dukungan pada ibu bisa diperoleh dari tiga pihak yaitu suami, keluarga, dan tenaga kesehatan, tetapi pengaruh dukungan yang paling besar memang dukungan yang diperoleh dari suami. Teori dari Friedman (1998 dikutip dalam Setiadi, 2008) juga menyebutkan bahwa dukungan sosial (keluarga) bisa berasal dari dua kelompok yaitu dukungan sosial eksternal (sahabat, pekerjaan, tetangga, sekolah, keluarga besar, kelompok sosial, kelompok rekreasi, tempat ibadah, praktisi kesehatan) dan internal (dari suami atau isteri, saudara kandung, dan anak).

Untuk dukungan informasional suami positif ada $38 \mathrm{ibu}(46,7 \%)$ yang terbagi atas $27 \mathrm{ibu}$ $(71,1 \%)$ tidak memberikan ASI eksklusif dan 11 ibu $(28,9 \%)$ memberikan ASI eksklusif. Bila dilihat dari hasil penelitian bahwa tingkat kemauan suami untuk mencarikan ibu informasi mengenai kehamilan dan menyusui masih jarang dilakukan kebanyakan suami. Ini menyebabkan informasi terpenting yang dibutuhkan oleh ibu selama hamil dan menyusui seperti manfaat dan keuntungan ASI ekslusif, cara perawatan payudara, cara memerah ASI dan memberikan ASI perahan, mengatasi kendala yang menghambat pengeluaran ASI, dan hal yang dapat mempengaruhi kelancaran ASI tidak diperoleh ibu dan juga suami. Sehingga kecenderungan untuk mengalami kendala selama proses menyusui sejak awal kelahiran bayi dan juga komitmen ibu untuk mengutamakan ASI sebagai nutrisi utama bayi akan tetap rendah.

Asumsi di atas terlihat dari hasil analisa peneliti bahwa masih banyak ibu yang tidak memberikan ASI eksklusif dengan alasan ASI tidak keluar di hari pertama, ASI kurang/tidak lancar, dan repot, sehingga ibu menggunakan susu formula sebagai nutrisi penganti dan pendamping ASI. Paparan iklan susu formula di media massa juga turut mempengaruhi para ibu untuk memilih susu formula sebagai alternatif utama. Sebagaimana pendapat Hegar dkk (2008) bahwa pemanfaatan susu formula semakin digemari ibu, karena pengaruh informasi lewat media masa lebih sering diperoleh ibu. Dari hasil Survei Kesehatan Rumah Tangga (SKRT) Tahun 2004, juga ditemukan bahwa alasan ibu-ibu menghentikan pemberian ASI eksklusif kepada bayinya, diantaranya produksi ASI kurang (32\%), pengaruh iklan susu formula (16\%) (Depkes RI, 2010). 
Hubungan Dukungan Penilaian Suami dan Pemberian ASI eksklusif

Berdasarkan hasil penelitian terlihat bahwa nilai $\mathrm{p}=0,011$. Hal ini menyatakan bahwa ada hubungan yang bermakna antara dukungan suami terhadap pemberian ASI eksklusif di wilayah kerja Puskesmas Lubuk Kilangan Kota Padang Tahun 2011.

Dari 37 ibu $(45,1)$ yang memiliki dukungan penialian negatif namun masih ada $2 \mathrm{ibu}$ $(5,4 \%)$ yang tetap memberikan ASI eksklusif dan 35 orang ibu $(93,6 \%)$ diantaranya tidak memberikan ASI eksklusif. Untuk 2 ibu yang tetap memberikan ASI eksklusif karena penilaian suami yang pernah disampaikan hanya berupa saran negatif kepada ibu untuk tidak menyusui, agar ibu tidak repot selain disusui bayi diberi susu formula dan saran negatif ini juga menurut ibu jarang disampaikan oleh suami, sementara saran suami kepada ibu yang bersifat mengkritik tidak pernah diucapkan suami sehingga ibu tetap semangat untuk tetap memberikan ASI hingga bayi usia 6 bulan.

Analisa tersebut sesuai dengan pendapat Roesli (2007) bahwa penilaian negatif yang diperoleh ibu dari suami yang paling sensitif dan bisa menjadikan ibu tidak mau dan tidak semangat untuk menyusui bayinya, yaitu apabila suami melontarkan kata-kata kritikan negatif seperti mengkritik perubahan pada tubuh isteri, payudara, dan bentuk tubuh. Selain itu dukungan emosional, instrumental dari para suami juga bernilai positif, sehingga penilaian yang saran negatif dari suami tidak mematahkan semangat ibu untuk tetap memberikan ASI eksklusifnya.

Dari 45 ibu (54,9\%) yang memiliki dukungan penilaian positif terdapat $12 \mathrm{ibu}(26,7 \%)$ yang memberikan ASI esklusif dan $33 \mathrm{ibu}(73,3 \%)$ yang tidak memberikan ASI eksklusif. Hal ini bisa terjadi karena disebabkan oleh faktor dari ibu sendiri yang memiliki penilaian negatif tentang dirinya terutama pada produksi ASInya pada minggu-minggu pertama pasca melahirkan. Hal ini terlihat dari hasil penelitian dimana masih ada beberapa ibu yang tidak memberikan ASI eksklusif dengan alasan bahwa ASI ibu tidak lancar/sedikit dihari pertama yaitu sebanyak 12 ibu (17,6\%), dan ibu berfikir bahwa bayi tidak kenyang bila hanya disusui sehingga bayi rewel sebanyak $10 \mathrm{ibu}(14,7 \%)$.

Penilaian negatif ibu pada analisa diatas dapat disebabkan oleh kurangnya atau tidak adanya informasi tentang jumlah dan produksi ASI yang memang berbeda-beda pada tiap waktunya, dimana pada hari pertama sampai hari kesepuluh produksi ASI ibu belum stabil yang sebenarnya normal, akan tetapi ibu tidak tahu. Ketidaktahuan ibu menjadi pemicu timbulnya penilaian yang negatif, sehingga ibu cemas dan kuwatir bahwa kebutuhan nutrisi bayi tidak akan mencukupi jika bayi hanya minum ASI saja dan pada akhirnya kecenderungan ibu untuk memilih alternatif dengan menambah atau mengganti ASI dengan susu formulapun dilakukan.

Dalam keadaan demikianlah dukungan seorang suami untuk mencarikan informasi mengenai ASI dan menyusui sebelum kelahiran bayi diperlukan agar penilaian negatif dan kekhawatiran ibu tidak terjadi. Dengan keterlibatan suami tersebut secara tidak langsung suami sudah menunjukkan bentuk dukungan kepada ibu untuk memberikan ASI eksklusif.

Hasil analisa multivariat tahap 3 yang terlihat pada tabel 5.19 menunjukkan bahwa ada dua variabel yang secara signifikan berhubungan dengan konsep dukungan suami yaitu dukungan emosional dan penilaian. Namun dukungan penilaian yang paling tinggi tingkat 
kekuatan hubungannya dengan pemberian ASI eksklusif.

Pada analisa multivariat ini terlihat bahwa dukungan penghargaan suami tampak yang paling berpengaruh terhadap keberhasilan pemberian ASI eksklusif di Wilayah Kerja Puskesmas Lubuk Kilangan Kota Padang tahun 2011. Hal ini sesuai dengan pendapat Setiadi (2006) bahwa bentuk penghargaan yang diberikan seseorang kepada orang lain berdasarkan kondisi sebenarnya. Penilaian bisa bersifat positif dan negatif yang mana pengaruhnya sangat berarti bagi seseorang. Berkaitan dengan keluarga maka penilaian yang sangat membantu adalah penilaian yang positif. Pengaruh positif dari dukungan sosial keluarga adalah penyesuaian terhadap kejadian dalam kehidupan yang penuh dengan stress.

Hal ini didukung juga oleh hasil penelitian dimana dari 14 ibu yang memberikan ASI eksklusif $12 \mathrm{ibu}$ diantaranya memiliki dukungan penilaian positif, dan 2 ibu yang memiliki dukungan penilaian negatif. Meskipun 2 orang ibu diantaranya memiliki dukungan penilaian suami negatif tetapi ibu tetap memberikan ASI eksklusif. Setelah dilakukan analisa diperoleh bahwa walaupun dukungan penilaian suami negatif tetapi ibu masih memperoleh dukungan emosional suami yang positif, dan pada analisa hasil kuesioner diperoleh juga bahwa penilaian negatif suami hanya berupa saran negatif yang tidak bersifat mengkritik bentuk atau perubahan fisik ibu yang dapat menimbulkan beban mental pada ibu.

Penilaian yang negatif berupa kata-kata kritikan secara tidak langsung akan mempengaruhi psikologis ibu yang akan berpengaruh pada kondisi emosional ibu menjadi tidak stabil. Sehingga hal tersebut akan menjadikan ibu tidak semangat untuk menyusui bayinya atau jumlah produksi ASI ibu akan berkurang atau tidak mencukupi kebutuhan bayi.

Analisa tersebut sesuai dengan pendapat Roesli (2007) bahwa penilaian negatif yang diperoleh ibu dari suami seperti kata-kata kritikan negatif pada perubahan tubuh ibu seperti payudara, dan bentuk tubuh bisa menjadikan ibu tidak mau dan tidak semangat untuk menyusui bayinya, untuk itu suami harus memberikan penilaian yang positif pada ibu seperti memberi semangat kepada ibu melalui kalimat-kalimat pujian, ungkapan kekaguman dan penghargaan kepada ibu, miliki sikap positif terhadap kehidupan pernikahan, sebisanya ikut bangun saat isteri terbangun tengah malam saat akan menysui bayi atau jika tak bisa bangun malam, paling tidak jangan tunjukkan ekspresi kesal akibat tidur yang terganggu saat bayi menangis lapar di malam hari.

Agar ASI dapat diproduksi dengan baik dan lancar diperlukan ketenangan fikiran, relaksasi, kedamaian, dan ibu tidak dalam keadaan cemas. Emosional ibu berpengaruh pada fungsi kerja hormon, sebagaimana dikatakan oleh Baskoro (2008) bahwa selama proses menyusui keadaan emosional ibu sangat mempengaruhi kelancaran pengeluaran ASI. Ada dua hormon yang berperan pada proses produksi dan pengeluaran ASI yaitu hormon oxytocin dan prolaktin, kedua hormon tersebut dalam produksinya sangat dipengaruhi oleh keadaan emosional seorang ibu.

Pemaparan di atas memperkuat bahwa dukungan suami terutama dukungan penilaian positif suami, merupakan salah satu hal yang memiliki pengaruh kuat sebagai pendukung terhadap keberhasilan pemberian ASI eksklusif. Dengan penilaian suami yang positif terhadap ibu maka emosional ibu juga akan 
tetap stabil sehingga produksi ASI ibupun lancar dan tentunya pemberian ASI eksklusif akan berhasil karena memiliki dukungan yang positif dari suami.

\section{Kesimpulan dan Saran}

Berdasarkan hasil penelitian dapat diambil kesimpulan sebagai berikut :

1. Terdapat dua dukungan suami dengan kategori positif yaitu dukungan instrumental $(56,1 \%)$ dan dukungan penilaian $(54,9 \%)$.

2. Terdapat dua dukungan suami dengan kategori negatif yaitu dukungan emosional $(52,5 \%)$ dan dukungan informasional $(53,6 \%)$.

3. Terdapat hubungan yang bermakna antara dukungan emosional, instrumental, informasional, dan penilaian suami terhadap pemberian ASI eksklusif ( $\mathrm{p}<$ $0,05)$.

4. Dukungan penilaian suami merupakan yang paling dominan terhadap pemberian ASI eksklusif dengan OR 0,11.

Sehingga disarankan bagi:

1. Institusi Pelayanan Kesehatan di Padang

Diharapkan kepada semua Institusi Kesehatan di Padang baik pemerintah dan swasta untuk lebih bisa memberikan dukungan dan perhatian terhadap upaya pemerintah yang ingin mewujudkan agar budaya penggunaan ASI eksklusif di Indonesia mengalami peningkatan pada tiap tahunnya. Salah satunya dengan melakukan inisiasi menyusu dini pada setiap ibu melahirkan selamat, agar target ASI nasional 80\% dapat tercapai.

2. Puskesmas Lubuk Kilangan

Diharapkan di Wilayah Kerja Puskesmas Lubuk Kilangan bisa menjadikan data-data survei mengenai kesehatan terutama ASI eksklusif yang rendah sebagai tolok ukur peningkatan kesadaran masyarakat peduli sehat terutama tercipta gerakan masyarakat pendukung ASI.

3. Tenaga Kesehatan

Diharapkan agar tenaga kesehatan terutama di Wilayah Kerja Puskesmas Lubuk Kilangan untuk lebih mengembangkan ide-ide baru dalam upaya meningkatkan keberhasilan ASI eksklusif terutama dengan promosi kesehatan dengan melibatkan suami sebagai sasaran pemberian informasi mengenai pentingnya dukungan suami kepada ibu menyusui.

4. Institusi Pendidikan

Disarankan agar materi perkulian terkait ASI dan menyusui tetap dipertahankan sebagai betuk dukungan perawat melalui pembekalan ilmu. Sehingga setelah bekerja nanti perawat mampu memberikan masukan positif kepada para suami dan ibu yang baru saja melahirkan untuk memberikan ASI eksklusif dan pemberian susu formula oleh tenaga kesehatan terutama perawat di instansi kesehatan seperti Rumah sakit dapat berkurang.

5. Peneliti Selanjutnya

Dalam penelitian ini peneliti belum memperoleh hasil penelitian yang baik meskipun dukungan suami memiliki pengaruh terhadap pemberian ASI eksklusif tetapi hasil penelitian ditemukan bahwa dukungan suami masih rendah dan cakupan ASI eksklusif ditempat penelitianpun masih rendah. Untuk itu peneliti menyarankan agar peneliti selanjutnya lebih menggali lagi penyebab permasalahan yang terkait rendahnya cakupan ASI eksklusif tersebut selain dari dukungan suami.

\section{Daftar Pustaka}

Amirudin, R., \& Rosita. (2007). Promosi susu formula menghambat pemberian asi eksklusif pada bayi 6-11 bulan di Kelurahan Pa'baeng-baeng Makasar tahun 2001. Bagian Epidemiologi FKM 
Unhas.

Arif, N. (2009). ASI dan tumbuh kembang bayi. Jakarta: Penerbit Media Pressindo.

Baskoro, A. (2008). ASI panduan praktis ibu menyusui. Yogyakarta: Banyu MediaWed. (2004). SDM mendatang tergantung ASI eksklusif. Diakses melalui http://www.gizi.net/ pada tanggal 15 November 2009.

Bonny \& Milla. (2003). 40 hari pasca persalinan masalah dan solusinya. Jakarta: Puspa Swara.

Departemen Kesehatan Republik Indonesia (Depkes RI). (2004). Kepmenkes RI No. 450/MENKES/IV/2004 tentang Pemberian Air Susu Ibu (ASI) secara Eksklusif pada Bayi Indonesia. Jakarta: Departemen Kesehatan RI.

Departemen Kesehatan Republik Indonesia (Depkes RI). (2010). Sambutan kepala perwakilan WHO Indonesia pada pekan ASI Sedunia 2010. Di akses dari http://gizi.net/download/pekanasi-2010.pdf tanggal 24 maret 2011.

Dinas Kesehatan Kota Padang (DKK Padang). (2009). Profil kesehatan Kota Padang tahun 2009 revisi 2010.

Dinas Kesehatan Provinsi Sumatra Barat. (2008). Profil kesehatan Sumatera Barat 2008 .

Februhartanty, J. (2008). Peran ayah dalam optimalisasi praktek pemberian ASI: Sebuah studi di daerah urban Jakarta. Di akses dari http://www.gizi.net/makalah/download/Su mmary Eng-Indo-Yudhi.pdf tanggal 24 Maret 2011.

Gumelar, L.A.S. (2010). Gerakan peduli ASI di Indonesia. Di akses dari http://www.metrotvnews.com/index.php/ metromain/news/2010/08/03/25050/Linda
-Gumelar-Pemberian-ASI-di-IndonesiaAmat-Rendah tanggal 24 Maret 2011.

Hegar, B., Suradi, R., Hendarto, A., \& Partiwi, I.G.Ayu. (2008). Bedah ASI. Jakarta: Ikatan Dokter Anak Indonesia (IDAI).

Linkages. (2002). Satu-satunya sumber cairan yang dibutuhkan bayi usia dini. Di akses dari

http://www.linkagesproject.org/media/pub lications/ENAReferences/Indonesia/Ref4. 7\%20.pdf pada tanggal 02 April 2011.

Paramita, R.P. (2007). Dukungan ayah dalam praktik Pemberian ASI masih minim. Di akses dari http://asipasti.blogspot.com/2008/02/duku ngan-ayah-dalam-praktik-pemberian.html tanggal 24 Maret 2011

Prasetyono, D.S. (2009). Buku pintar ASI eksklusif. Jogjakarta: DIVA Press.

Ramaiah, S. (2007). ASI dan menyusui. Jakarta: PT Bhuana Ilmu Populer (Kelompok Gramedia).

Roesli, U. (2000). Mengenal ASI eksklusif. Jakarta: Trubus Agriwidya.

Roesli, U. (2008). Inisiasi menyusu dini. Jakarta: Pustaka Bunda.

Roesli, U. (2001). Bayi sehat berkat ASI eksklusif. Jakarta: Elex Media Komputindo.

Roesli, U. (2010). Ayah ASI, bagaimana peranannya. $\mathrm{Di}$ akses dari http://female.kompas.com/read/2010/05/16/151 31560/ayah.asi.bagaimana.perannya tanggal 24 Maret 2011. 
Setiadi. (2008). Konsep dan proses keperawatan keluarga. Yogyakarta: Penerbit Graha Ilmu.

Sri P.H. (2004). Konsep penerapan ASI eksklusif. Jakarta: Buku Kedokteran EGC.

Suparyanto. (2010). Konsep ASI eksklusif. Di akses dari http//kuliah bidan.net/dr Suparyanto, M_Kes KONSEP ASI EKSKLUSIF.mht tanggal 24 Maret 2011.

Survei Demografi dan Kesehatan Indonesia (SDKI). (2010). Data SDKI tentang ibu yang menyusui. $\mathrm{Di}$ akses dari http://www.pdfwindows.com/pdf/datasdki-tentang-ibu-yang-menyusui/tanggal
24 Maret 2011.

Tasya, A. (2008). Indonesia dan ASI. Di akses dari http://aimi-asi.org/2008/08/indonesiadan-asi tanggal 29 September 2010/.

Wahit, I., dkk. (2006). Ilmu keperawatan komunitas 2. Jakarta: Penerbit Agung Seto.

Welford, H. (2008). Menyusui bayi anda. Jakarta: Penerbit Dian Rakyat.

Wijayakusuma. (2008). Peran suami dalam mendeteksi tanda kehamilan. Diakses dari http://www.ciberindo-aditama pada $\begin{array}{llll}\text { tanggal } & 19 \quad \text { Maret } & 2010 .\end{array}$ 